4. Старости в об'єднаних громадах. URL : https://decentralization.gov.ua/starosta (дата звернення: 20.01.2019).

5. Коновалов В. Визначити правові засади діяльності старости. URL: https://decentralization. gov.ua/starosta (дата звернення: 20.01.2019).

6. Про внесення змін до деяких законів України щодо статусу старости села, селища: Закон України 9 лютого 2017 року № 1848-VIII. URL : https://zakon.rada.gov.ua/laws/show/1848-19/ print (дата звернення: 20.01.2019).

7. Радник Старости. URL : https://old.decentralization.gov.ua/pics/attachments/radnik starosti 0117 u.pdf (дата звернення: 20.01.2019).

$\overline{8}$. Старости в селах об'єднаних громад: що змінює новий закон. URL : http://decentralization. gov.ua/news/item/id/4433 (дата звернення: 20.01.2019).

9. Брусенцова Я. Староста, його статус, повноваження: вивчаємо знову. URL : https://i.factor.ua/ukr/journals/rs/2017/april/issue-1/article-32913.html (дата звернення: 20.01.2019).

10. Про віднесення посад органів місцевого самоврядування до відповідних категорій: Постанова КМУ від 26 жовтня 2001 року № 1441 / Кабінет Міністрів України. URL : https://zakon. rada.gov.ua/laws/show/1441-2001-\%D0\%BF (дата звернення: 20.01.2019).

11. Про службу в органах місцевого самоврядування : Закон України від 7 червня 2001 року № 2493-III / Верховна Рада України. URL : https://zakon.rada.gov.ua/laws/show/2493-14/ print (дата звернення: 20.01.2019).

12. Чи потрібно розробляти посадову інструкцію старости: роз'яснення та поради фахівця. URL : https://decentralization (дата звернення: 20.01.2019).

УДК 342:001.5(091):165.321+342.4

DOI https://doi.org/10.32844/2618-1258.2019.3-2.9

ЯкИМОВИч Я.В.

\title{
СИСТЕМА ВИТОКІВ АТРОПОЦЕТРИЗМУ У ФОРМУВАННІ СУЧАСНОГО КОНСТИТУЦІОНАЛІЗМУ ДЕРЖАВНОЇ ВЛАДИ
}

Явище антопоцентризму в державій владі існувало завжди та, починаючи від перших державовладних утворень, виражалося в різноманітних поглядах, концепціях, підходах. У цьогочасному суспільстві з розвитком демократичних форм державного режиму та інтенсивністю державотворчих процесів усе більшого значення набувають знання, вміння, навички, досвід (людський чинник) самого суб'єкта владних повноважень, що і зумовлює актуальність зазначеного явища. Незважаючи на це, наведена тематика найбільше розробляється в соціології права, політології, філософії права, а також в окремих підходах адміністративного права. У конституційному ж праві цей напрямок досліджений тільки окремими поглядами, викладеними в дисертаціях, та загальними думками щодо суб'єктів конституційно-правових відносин. Проте явище людського чинника повинно бути вивчене на фундаменті основного закону в першу чергу, оскільки саме від вимог конституційної дієздатності, прав, дискреційних повноважень, обов'язків та інших елементів конституційно-правового статусу воно отримує свої витоки і можливість бути реалізованим та впливати на державотворчі процеси.

У цій статті антропоцентризм досліджується з точки зору чотирьох позицій та п’яти критеріїв. До основних позицій належать історичний, емпіричний (практика державотворчих подій та процесів), доктринально-правовий та нормативно-конституційний підходи. Комплексний характер дозволяє відобразити перехід явища з однієї позиції в іншу, ілюструючи тенденційність розвитку. П’ять критеріїв

(C) ЯКИМОВИЧ Я.В. - аспірант кафедри конституційного права та порівняльного правознавства (Ужгородський національний університет) 
(правителі (царі), адміністрація, місце людини в державній владі, інтерес та закон) дозволяють забезпечити збереження сутності явища антропоцентризму у процесах переходів. Дослідження супроводжується розумінням індивідуалізованого суб'єкта публічної влади (законодавчої - в парламентарях, виконавчої - у президентові та урядовцях, а судової- у суддях).

Такий підхід систематизує знання про характерні ознаки антропоцентризму та створює передумови для теоретичного визначення ролі і місця цього явища в конституціоналізмі сучасної державної влади. У перспективі свого розвитку це явище дозволить ретельніше готувати нормативну основу для використання людського чинника в державотворчих процесах, що сприятиме їхньому розвитку.

Ключові слова: людський чинник, вимоги до правителів, адміністрація, місче людини в механізмі державної влади, інтерес, закон, історичний, практичний, доктринальний, нормативно-конституиійній підхід.

The phenomenon of anthropocentrism in the state power has always existed and, from the first state power formations, was expressed in different views, concepts, approaches. In this modern society, with the development of democratic forms of state regime and the intensity of state-making processes, knowledge, skills, experience (human acting ) of the subject of power, which determines the relevance of the phenomenon, are becoming increasingly important. Nevertheless, these topics are mostly developed in the sociology of law, political science, philosophy of law, as well as in some approaches to administrative law. In the constitutional law, this area is explored only by the specific views expressed in the dissertations and the common views on the subjects of constitutional-legal relations. However, the phenomenon of the human factor must be studied on the basis of the constitution in the first place, because it is from the requirements of constitutional capacity, rights, discretionary powers, duties and other elements of constitutional legal status that it receives its origins and the ability to be realized and influence the state processes.

In this article, anthropocentrism is explored in terms of four positions and five criteria. The main positions include historical, empirical (practice of state-making events and processes), doctrinal-legal and normative-constitutional approaches. The complex view allows to reflect the transition of the phenomenon from one position to another, illustrating the tendency of development. Five criteria (rulers (kings), administration, place of a person in state power, interest and law) allows to preserve the essence of the phenomenon of anthropocentrism in the processes of transition. The study is accompanied by an understanding of the individual subject of public authority (legislative - in parliamentarians, executive - in president and government officials, and judicial - in judges).

This approach systematizes knowledge about the characteristic features of anthropocentrism and creates the prerequisites for the theoretical definition of the role and place of this phenomenon in the constitutionalism of modern state power. In the perspective of its development, this phenomenon will allow to prepare more carefully the normative basis for the use of the human acting in the state-making processes, which will facilitate their development.

Key words: human factor, requirements for rulers, administration, place of a person in the mechanism of state power, interest, law, historical, practical, doctrinal, normativeconstitutional approach.

Вступ. Існування антропоцентризму в тій чи іншій формі було притаманне як фундаментальним поглядам перших науковців та філософів на державу, так і сучасному практичному функціонуванню організації державної влади, науковій доктрині та сучасному конституціоналізму в цілому через норми основних законів. У рамках теоретичного огляду спробуємо відобразити процес переходу від первинних антропоцентричних ідей до їхньої сучасної конституційної реалізації.

Постановка завдання. Дослідження системи витоків антропоцентризму в державній владі може бути здійснено тільки крізь призму індивідуалізації суб'єктів конституційно- 
правових відносин центральних органів публічної влади. Таким чином, елемент anthropos (грець. $\not \alpha v \theta \rho \omega \pi о \varsigma)$ у законодавчій владі втілюватиметься в суб'єктах парламентаризму (парламентарях), у виконавчій - урядовцях та президентові, а в судовій - через самих суддів. У свою чергу, еле-

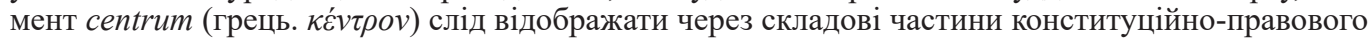
статусу, який отримує особа внаслідок набуття своїх повноважень (гарантії, права, дискреційні, повноваження, обов'язки, заборони, обмеження та участь у колективному антропоцентризмі).

Виходячи з раніше проведених досліджень, погляди на антропоцентризм у державній владі можна розподілити за категоріями: правителі (вимоги дієздатності иุарів), адміністрація, місие людини в державній організації, інтерес та закон [60]. Змістом системи переходу одних явищ в інші стане аналіз кожної категорії з точки зору практики сучасного державотворення, доктринальних підходів та їхнього нормативно-конституційного втілення $[58 ; 59 ; 61 ; 57]$. Для чіткості аналізу після огляду кожного критерію будуть наведені короткі висновки, якими узагальнюватимуться описані процеси.

Результати дослідження. Історичні погляди, пов'язані із правителями (царі), найчастіше формувалися на вимогах, які ставилися перед ними. На початку ці вимоги стосувалися способу мислення та стилю життя (Платон) [37, с. 35]. Із часом вони вдосконалювалися та стосувалися певного досвіду та знань, як, наприклад, обізнаність, мудрість, компетентність та красномовність (М.Т. Цицерон). Для періодів військового часу необхідними були військовий вишкіл, фізична досконалість та хоробрість (Ібн Рушт) [5, с. 27, 39]. У період розвитку дипломатичних зв'язків Н. Мак'явеллі наголошував на вмінні перетворюватися із лева в лисицю. Бути левом, щоб вовків відганяти, а лисицею - щоб сильце обійти [21, с. 187]. Хоча і в різних контекстах, проте як Т. Компанелла, так і Г. Сковорода писали про певну приналежність до царювання, що дана від природи та є сродною працею правителя [31, с. $141 ; 5$, с. 204].

Сучасна практика державного правління ілюструє приклади необхідного досвіду для досягнення державотворчої мети та прийняття рішень. Зокрема, досвід знань міністра закордонних справ Республіки Польща К. Скубішевського відіграв значну роль у роботі Президента Республіки Польща О. Кваснєвського над вступом Польщі до Європейського Союзу та НАТО [17, с. 352]. Президент Франції Ф. Олланд отримав досвід від одного зі своїх попередників, Жака Ширака, щодо портретів та процесів у політичному житті [36, с. 159]. Невід'ємним є досвід отриманих знань внаслідок освіти, що допомогло Ф. Олланду прийняти належне рішення в податковій та бюджетно-видатковій системі Франції у 2013 році. Вагоме значення мають рішення, пов'язані 3 військовими операціями, оскільки від них залежить життя військовослужбовців [36, с. 207; 8]. У державно-організаційному процесі важливими є питання урядових призначень. Від цих рішень залежить спосіб та ефективність ведення державних справ. Саме ж призначення може здійснюватися за політичною логікою та (або) особистими міркуваннями, як у випадку із Жаном-Марко Еро - прем'єр-міністром Франції, який був призначений, виходячи саме з наведених критеріїв [36, с. 310, 319]. Для прийняття подібних рішень необхідно мати ефективне стратегічне та тактичне мислення як у військовій справі, так і в державному будівництві. Окремої уваги заслуговує також індивідуальна активність керівників держави. Н. Саркозі за свого президентства встановив контроль над бюджетом Слісейського палацу, Національним аудиторським офісом Франції, реформував університети, пенсійну систему, провів конституційну реформу та багато іншого [6; 35]. За відносно короткий термін перебування на посаді (2007-2012 рр.) без досвіду роботи та здібностей подібні реформи були б складні в реалізації.

Правова доктрина звертає увагу на доступність громадян до тих чи інших повноважень у демократичних країнах. Така доступність бере свій початок із правових, зафіксованих в основному законі можливостей, зокрема, права на участь в управлінні державними справами, про що зазначає О.О. Чуб у праці «Конституційне право громадян України на участь в управлінні державними справами» [50, с. 11]. У цьому контексті пріоритетним стає не просто вміння, навички, спосіб мислення, знання чи досвід правителя, а юридична можливість виконувати повноваження. Це дозволяє особі бути суб'єктом державотворчих відносин незалежно від свого людського чинника (знань, умінь і навичок). Дослідники А.С. Смілик та О.Я. Зубрицька акцентують увагу на індивідуальному суверенітеті особи, який базується на таких елементах, як: вік, характер, емоційні якості, інтелект, переконання, психологічний стан та інші складові частини, що впливають на правове становище та виконання повноважень суб'єктів публічної влади [45, с. 95; 19, с. 179]. О.Л. Терент'єва звертає увагу на менталітет як чинник розвитку державного будівництва $[47$, с. 8]. На думку А.В. Матіоса, сучасне державне управління пов'язане як із реальними суспільними процесами, так і зі свідомістю, певними формами знань, доктринами, теоріями та 
концепціями [29, с. 17]. М.I. Салей запропонувала конституційний механізм, який складається із ціннісно-нормативної бази, інтелектуально-вольової основи та поведінково-динамічного компоненту. Два останні елементи відображають місце та роль людського чинника у сучасному конституціоналізмі та державній організації [43, с. 183]. Подібні елементи застосовуються Ю.Г. Барабашем під час теоретизації дискреційних повноважень державного службовця, які мають вольову та інтелектуальну складові частини, що також підкреслює значення потенціалу особистості в державному функціонуванні [4, с. 17].

Із конституційно-правової точки зору вимоги та пропозиції науковців, наведені в історичному огляді, сьогодні реалізуються перш за все через конституційну дієздатність. Тобто в арсеналі цензів, яким повинна відповідати особа для набуття повноважень. Така відповідність вольовий та інтелектуальний елемент здатності особи реалізовувати як своє виборче право, так і право на участь в управлінні державними справами. До основних вимог належать: приналежність до громадянства, вікова зрілість, здатність обирати та бути обраним, чіткий період проживання на відповідній території, відсутність судимості (моральний ценз). У Конституції України (далі - КУ) для глави держави та суддів передбачено знання державної мови (ч. 2 ст. 103, ч. 3 ст. 127 КУ), що пов'язано 3 територіально-історичною специфікою розвитку країни [20]. Слід виділити те, що тільки судовій гілці влади притаманні вимоги освіти та кваліфікації. Щодо президента, уряду (на рівні конституції) чи парламенту вони не застосовані.

У такий спосіб на історичному етапі вимоги до правителів мали зв'язок із політичними обставинами та викликами в суспільстві. У період формування державних організацій необхідні були інтелектуальні здібності та філософське бачення, в період воєн - військові здібності, хоробрість та добра пам'ять, а для періоду дипломатичних відносин важливими стали мудрість та винахідливість (послідовність у діях). На сучасному етапі розвитку практика державного правління вимагає необхідність досвіду як в освіті, знаннях політичного життя, так і у військових справах. Правова доктрина ілюструє схеми конституційних механізмів, у яких основну роль відграють інтелектуально-вольові та поведінкові елементи. Вона виокремлює людський чинник через індивідуальний суверенітет особи, залишаючи вагому роль юридичній можливості участі в державних справах та дискреції при реалізацї цього ж таки людського чинника. Конституційним оформленням зазначених процесів виступають норми конституційної дієздатності, які на правовому рівні встановлюють можливості та обмеження під час доступу до реалізації права на участь в управлінні державними справами.

Існування адміністрації та її зародження пов'язане з явищами диференціації (М. Вебер) та спеціалізації (Г. Спенсер). Ці процеси полягали в розподілі повноважень правителя на різноманітні сфери та концентрації цих повноважень у руках людей (робочих груп), які мали схильність, здібності або знання до виконання певного роду роботи [5, с. 369-371, 295]. Наприклад, T. Кампанелла у праці «Місто Сонця» повноваження, пов'язані $з$ військом, надав Силі, наука виконувалася Мудрістю, а виховання дітей та жнива - Любов’ю [31, с. 135-138]. Таким чином, вони не концентрувалися в одних руках, а були надані різним здібним урядовцям, що є прикладом процесів диференціації, а особливо спеціалізації. На певний порядок взаємовідносин між правителем та урядовцями акцентував Конфуцій, звертаючи увагу на необхідність пробачати дрібні помилки працівникам і залучати до служби доброчесних та здібних. Жан Боден описував рішення, яке повинне прийматися в результаті ретельного розгляду та мудрих порад найпроникливіших радників та управителів [5, с. 32-33, 73].

Практика державного правління виокремлює такі особистості, як Л. Фабіус та М. Нефьодов. Перший - міністр закордонних справ Франції, який під час доповідей, окрім елегантності та чіткості висловлення, відрізнявся докладністю, грунтовністю виступу, деталізацією питань внутрішнього становища окремих країн, що свідчить про його працьовитість [36, с. 31, 34]. Другий - заступник міністра економічного розвитку і торгівлі України, маючи економічну освіту, досвід роботи інвестиційного банкіра та будучи прихильником сучасних методів ведення бізнесу, став натхненником тендерної платформи «Прозоро». За допомогою цієї платформи можна відкрито (публічно) та на рівних умовах здійснювати закупівлю і продаж державного майна [32; 33]. Ці державні службовці завдяки власним здібностям та знанням сприяли розвитку своїх країн на міжнародному та внутрішньодержавному рівнях. Часто рішення для належного прийняття потребують комплексного обмірковування. Наприклад, у справі з Леонардою Дібрані французькою школяркою із сім’ї емігрантів, яку було затримано, коли та поверталася зі школи (що швидко сколихнуло французьке суспільство), рішення про громадянство приймалося Президентом Франції за згоди та порадами міністра внутрішніх справ, міністра національної освіти та 
прем'єр-міністра. Така згода дозволила отримати вихід із відхиленням від закону відповідно до ситуації [36, с. 268-273].

Ілюстрацією підбору урядових кадрів може бути ситуація із Прем’єр-міністром Республіки Польща М. Маровецьким, який після вступу на посаду замінив тільки половину складу попереднього уряду. Керівник виконавчої влади сам обирає, з ким співпрацювати [18].

Із точки зору правової науки найменшою організаційною одиницею публічного управління є людина-громадянин. Вона повинна бути наділена правовою культурою, яка включає в себе: 1) знання і розуміння законодавства; 2) творчий рівень використання правового інструментарію; 3) розуміння соціально-правової значущості та цінності прав людини; 4) правове мислення; 5) внутрішню необхідність дотримуватися правової поведінки; 6) професіоналізм державного службовця як явища, що поєднує вищезазначені елементи (знання, вміння, навички, практичний досвід, індивідуальні особливості) у процесі виконання державної служби та формування базисного підгрунтя соціальних перетворень [25, с. $19 ; 34$, с. 8$]$.

Конституційне формулювання, що на правовій основі дозволяє реалізовувати вищезазначене та оцінювати його як частину сучасного конституціоналізму, відображається через призначення, які здійснюються на власний розсуд або за пропозицією відповідних суб'єктів публічної влади. Так, Президент України здійснює призначення глав дипломатичних представництв (п. 5 ст. 106 КУ). Під час подання на призначення Міністра оборони України та Міністра закордонних справ України (п. 10 ст. 106 КУ) глава заручається належною підтримкою у процесі прийнятті рішень Ради національної безпеки та оборони України, яку він очолює (п. 18 ст. 106 КУ) [20]. Президент Польщі висуває, а згодом призначає кандидатуру на посаду Голови Ради Міністрів Республіки Польща, який пропонує склад Ради Міністрів (п. 4 ст. 162 Конституція Республіки Польща (далі - КП)) [3; 51]. Президент Франції згідно зі статтею 8 Конституції Французької Республіки (далі КФ) призначає керівника уряду і за його поданням інших членів уряду, а згідно зі статтею 9 глава цієї держави головує на засіданнях Ради міністрів, що є напівурядовим органом у Франції (не урядом, але складається з міністрів) $[1 ; 52]$. Це дозволяє приймати рішення у ситуаціях, як вищеописана з Леонардою Дібрані. Можливість розсуду під час призначення урядовців надає зв'язки, що забезпечують прийняття ретельніших та результативніших державотворчих рішень, узгодження позицій, проведення ефективніших консультацій і зменшення ризику конфлікту між суб’єктами влади у відносинах контрасигнації.

Таким чином, необхідність у здібних помічниках правителя та урядовцях виникла в результаті історичних тенденцій диференціації та спеціалізації. Сьогодні вони переросли у складність прийнятого колективного державотворчого чи суспільно вагомого рішення, за якого кожний суб'єкт публічної влади та суб'єкт прийняття цього рішення (як керівник, так і підлеглий урядовець) набуває значення найменшої організаційної одиниці суспільного правління (людини). Ця одиниця повинна бути наповнена правовою культурою та професіоналізмом під час виконання своїх конституційних повноважень, які, у свою чергу, сприяють реалізації іiї державотворчих візій. У такий спосіб відтворюється структура антропоцентризму адміністративної взаємодії в конституціоналізмі сучасних держав.

Визначення місця людини в державній владi пройшло тривалий та непростий шлях, належний виклад якого потребує окремого дослідження. Проте загальні риси все ж можна виділити. У першу чергу слід зазначити, що визначення місця людини в державній владі - це складний процес взаємодії двох точок зору, у яких, з одного боку, людина $є$ первинною та основною ланкою всієї організації, а з іншого, людина - гвинтик великого державного механізму, що не відіграє в ньому основної ролі (підхід, який за останні століття був панівним). Представником останньої точки зору слід вважати Й.- Г. Гердера, який у період розвитку механістичних уявлень про природу людини 18 століття стверджував, що людина народжена для суспільства [15, с. 604]. Ці погляди пізніше були взяті до уваги та активно розвивалися в комуністичних і соціалістичних ідеологіях. На противагу цьому існували гуманістичні засади політичної антропології, які виникли раніше. Т. Гоббс, порівнюючи державу з морським чудовиськом, стверджував, що функції його органів (м'язи, нерви) виконують люди або групи людей. При цьому вони не матеріал формування держави, а є iї творцями та розпорядниками $[13$, с. 184, 238, 296]. Несправедливість держави, вважав Ш.Л. Монтеск'є, полягає не в її механізмі чи конструкції, а в урядовцях та інших державних службовцях. Він стверджував, що монархія гине, коли правитель ототожнює державу із своєю столицею, столицю - із двором, а двір - із своєю особою [5, с. 103]. Г. Гегель акцентував увагу не тільки на людині в державі, але також на державній свідомості людини, якою вона повинна бути наділена у процесі прийняття рішень [12. с. 261]. Рішення, прийняті крізь призму державної 
свідомості згідно з Е. Агацці, набувають ціннісного характеру та «внутрішньої належності», оскільки випливають із переконань, досвіду та здібностей особи [49, с. 146]. Т. Джеферсон стверджував, що влада і право може належати лише людям, а не матерії, яка позбавлена волі [5, с. 137].

Практика державного правління відображає значення людини в державному механізмі через активність глав держав у державотворчих процесах та вплив міжособистісних зв'язків на світовий розвиток. Наприклад, особиста активність п'ятого Президента України П.О. Порошенка, який після вступу на пост отримав країну з дуже низькими бюджетними показниками, майже небоєздатною армією та міжнародним військовим конфліктом. Протягом п'яти років виконання повноважень глави держави вдалося отримати безвізовий режим із країнами Європи, підписати політичну та економічну частину Угоди про асоціацію України з Свропейським Союзом, консолідувати міжнародну спільноту для ізоляції країни-агресора, ефективно модернізувати армію та почати проведення великої кількості реформ української державності (судова, поліції, медицини, децентралізації та інші) [8]. Так само завдяки активності Президента Республіки Польща О. Кваснєвського країна 3 постсоціалістичним минулим за короткий час зуміла стати членом НАTO та Європейського Союзу. Це стало можливим у результаті налагодженої системи дипломатичних зв'язків із НАТО, проведення багаторазових зустрічей із генеральними секретарями, численних поїздок до держав-членів та проведення спільних програм. ЄС стало відкритим завдяки проведенню перемовин, які завершилися підписанням угод та різноманітних програм, наприклад: «Національної стратегії інтеграції», «Партнерства заради членства», «Програми дій щодо адаптації економіки та правової системи до вимог «Угоди про асоційоване членство» та ін. $[17$, с. 353-355]. Невід'ємне значення мають також міжособистісні зв'язки, що впливають на світові процеси. Прикладом таких зв'язків стала Конференція ООН із питань клімату СОР-21 (2015р.). Тоді для згоди Нікарагуа підписати угоду про зменшення видобутку викопних енергоносіїв та збільшення альтернативних джерел енергії Ф. Олландом було залучено Папу Римського Франциска, який, підтримуючи зв'язки з колишніми сандиністами (членами нікарагуанської партії «Сандиністський фронт національного визволення»), зумів вплинути на позитивне рішення керівників цієї держави [5, c. 191].

Доктринальне розуміння людини в державному механізмі сьогодні, виходячи із поглядів М.В. Серебро - автора праці «Сучасна держава як цінність: загальнотеоретичне дослідження», слід розглядати через ідею особистості як аксіологічної сутності держави $[44$, с. 5]. Це означає, що людина - не просто частина організації, а виступає ії цінністю, основним первинним елементом. Визначення місця людини в державній владі відбувається через призму іiї статусу. Посадова особа, згідно з Н.В. Янюк, - це об'єктивний суб'єкт будь-якої організаційної структури [62, с. 8]. Набуття повноважень та отримання статусу суб'єкта владних повноважень означає відмову від частини свободи, яка перетворюється на необхідність, підкріплену відповідальністю, у цьому відображається як вибір людини, так і прояв ії̈ волі. Проте відмова від частини свободи веде до набуття елементів статусу. Чотирма основними елементами вважаються гарантії, права, обов'язки та відповідальність $[62$, с. $10 ; 42$, с. $13 ; 6$, с. $68 ; 53$, с. 9]. Вагомого значення у цьому контексті набуває елемент правової ідентичності як способу усвідомлення особою своєї ролі (відповідно прав, обов'язків та відповідальності) у правовій системі держави [38, с. 83].

Із точки зору норм конституційного законодавства, як і правової доктрини, людина в державній владі закріплюється статусом, тобто набутими гарантіями (п. 5 ст. 105 КП - заборонено затримання депутатів без згоди Сейму), правами (п. 30 ст. 106 КУ - Президент має право вето щодо прийнятих Верховною Радою України законів), обов'язками (п. 15 ст. 106 КУ - Президент зупиняє дію актів уряду з мотивів невідповідності Конституції України зі зверненням до Конституційного Суду України щодо їхньої конституційності). У законодавстві також до елементів статусу належать: дискреційні повноваження (пункт а) ст. 62 Конституції Чеської Республіки (далі - КЧ) - Президент призначає керівника уряду та інших членів уряду), заборони (п. 2 ст. 100 КП - неможливо одночасно бути членом Сейму та Сенату), обмеження (ч. 1 ст. 68 КФ - Президент за порушення, явно несумісні зі здійсненням мандата, може бути усунений із посади), норми конституційної дієздатності (п. 1, п. 2 ст. 99 КП - депутатом може бути громадянин Польщі, який досяг 21 року та має право голосу) та участь у колективному антропоцентризмі (п. 3 ст. 98 КП - Сейм може скоротити термін своїх повноважень шляхом прийняття постанови більшістю голосів щонайменше $2 \backslash 3$ від загального складу депутатів). Безперечно, варто враховувати і відповідальність, однак у рамках нашого дослідження цей елемент був взятий до уваги тільки описово. Статус суб' єкта владних повноважень особа може отримати шляхом реалізації свого права на участь в управлінні державними справами, яке $\epsilon$ конституційним правом кожного громадянина, що відповідає вимогам конституційної дієздатності $[1 ; 52 ; 2 ; 3 ; 51 ; 20]$. 
Таким чином, можна простежити значення людини в державному механізмі, яке, хоч i супроводжується ідеологічними суперечностями, які, на наш погляд, є результатом різного трактування класичних міркувань, та все ж визначає особу творцем і розпорядником державної організації. Активність та здібності глав держав, які впливають на ефективність розвитку своїх країн через практику сучасного публічного управління, тільки підтверджують зазначені історичні погляди. Ці погляди та практика управління дозволяють правовій доктрині, визнаючи особу аксіологічною сутністю держави, вказувати на те, що вона - об’ єктивний суб’єкт будь-якої організаційної структури. Основою реалізації всіх цих підходів є сукупність можливостей (гарантії, права, дискреційні повноваження, колективний антропоцентризм) та необхідностей (обов'язки, заборони, обмеження, конституційна дієздатність), передбачених конституційним законодавством. Вони формують поняття статусу суб'єкта владних повноважень, який може бути здобутий тільки через конституційне право громадянина на участь в управлінні державними справами.

Невід'ємне значення для визначення антропоцентризму в конституціоналізмі сучасної держави має поняття інтересу. Крізь призму історичного підходу у класично-правовому вигляді це поняття було започатковане Рудольфом фон Єрингом. Його впровадження сприяло чіткішому розмежуванню публічного і приватного інтересу [30, с. 79]. Науковці зазначають, що Р. Єринг у такий спосіб обгрунтував право як похідне від суспільних відносин, рушійною силою яких є людський та колективний інтерес [28, с. 35]. Із цього приводу Н. Мак'явеллі, відображаючи зв'язок між тими, хто вибирає, та тими, кого вибирають, наводив приклад правителя, який, будучи обраний простими людьми, захищав їхні інтереси. Якби цей правитель був обраний знаттю, захищаючи інтереси верхівки суспільства, не мав би підтримки серед нижчих за класом громадян $[27$, c. 442$]$. Ф. Гегель щодо інтересу наголошував на питанні ототожнення особистого та загального в державі [5, с. 219]. Дж. Локк також зазначав про можливий негативний прояв інтересу. Він указував на необхідність судді, який не мав би пристрастей, тобто його діяльність не була зумовлена інтересом, який міг би вплинути на справедливість рішення [5, с. 96]. Ш. Монтеск'є писав про інститут цензорів, який би наглядав за діями та моральністю громадян і посадових осіб, сприяючи балансу між інтересами особи та її повноваженнями [5, с. 104].

Практика сучасного державотворення ілюструє інтерес через цілу низку рішень, прийняття яких відштовхувалося від зазначеного поняття. В. Гавел, перший Президент Чеської Республіки, готуючись до зустрічі з головами партій, для позитивного вирішення питання запроваджував порядок денний, у якому перші п'ять пунктів відповідали інтересам усіх суб'єктів обговорення (з ними всі погоджувалися) [11, с. 123]. Із точки зору колективного антропоцентризму та надання переваги публічному інтересу перед приватним цікавим $є$ приклад Парламенту Республіки Польща, депутати якого під час урядового конфлікту щодо надання високих премій проголосували за зниження своєї заробітної плати на 20\%) [48]. Л. Кравчук - перший Президент незалежної України, керуючись інтересом молодої держави, відмовився від ядерного арсеналу взамін на міжнародний захист суверенітету. Це обгрунтовувалося тим, що Україна не позиціонувала себе як країна-агресор чи така, що прагне до війни, але, з іншого боку, має необхідність у міжнародному визнанні та створенні позитивного іміджу. Л. Кравчук писав: «Україна не могла управляти ракетами, управління було в Москві. Америка страшно боялася цих ракет тому, що всі боєголовки в Україні були націлені на США. А в нас було 175 ракет. Що з ними робити? Тому про зброю я не шкодую: на той момент це було єдине правильне рішення» [54, с. 130].

Правова доктрина з точки зору антропоцентризму в сучасному конституціоналізмі в контексті інтересу звертає увагу на інтеракцію між суверенітетом особи (свобода, самостійність, приватна філософія, індивідуальне вдосконалення) та суверенітетом держави (внутрішні та зовнішні питання в державі) [24, с. 7]. У таких відносинах виникає конфлікт інтересів, коли людина, показуючи видиму модель поведінки, може діяти із правилами іншої моделі, тобто мати інші інтереси, ніж це передбачено правовою регламентацією в рамках повноважень та відповідно до державного інтересу [41, с. 13]. Інтерес як частина орієнтації людини має два фактори впливу - зовнішній (сім'я, засоби масової інформації, органи публічної влади) та внутрішній (самоаналіз, самокритика та інші способи визначення власної системи цінностей) [43, с. 11]. Ці фактори впливають на трансформацію свідомості як суддів, президентів, так і парламентарів чи урядовців [23, с. 17]. Тобто інтерес, як і особистість, завжди перебуває у динамічному процесі. А.В. Матіос у праці «Адміністративна відповідальність посадових осіб у сфері державного управління» стверджує, що службовець повинен ставити державні інтереси вище, ніж індивідуальні, використовувати найбільш ефективні та раціональні способи виконання обов'язків [29, с. 13]. 
Нормативно-конституційною формою прояву інтересу в сучасних основних законах $\epsilon$ поділ права на публічне та приватне. Публічне право втілюється, наприклад, через можливість звернення Президента Польщі до Конституційного Трибуналу про відповідність міжнародних договорів конституції перед їх підписанням, що передбачено п. 2 ст. 133 КП [3; 51]. Норми, які врегульовують приватне право, можна також поділити на особисто-приватне та суспільно приватне (загально-приватне). Прикладом особисто-приватного права може бути п. 1 ч. 2 ст. 81 КУ, згідно 3 яким народний депутат може скласти свої повноваження за особистою заявою [20]. Тобто до цієї категорії відносяться норми, що стосуються індивідуально суб'єктів публічної влади. До норм загально-приватної категорії можна віднести статтю 17 КЧ, згідно 3 якою Президент Чехії може здійснювати помилування на персональній основі [2]. До суспільно-приватної категорії також можна віднести норми, пов'язані із прийняттям до громадянства та наданням нагород (оскільки йдеться про особистий здобуток особи), якщо вони зафіксовані в конституційному законодавстві. Врегулювання основним законом приватного інтересу також відображене в: обов'язках - ч. 1 ст. 129 КУ, згідно з якою суддя $\epsilon$ незалежним та керується верховенством права; заборонах - п. 4 ст. 103 КУ, згідно з якою Президент України не може займатися іншою оплачуваною чи підприємницькою діяльністю; обмеженнях - п. 5 ч. 5 ст. 126 КУ, якою передбачено звільнення судді за незгоду на переведення до іншого суду в разі ліквідації чи реорганізації суду, в якому суддя обіймав посаду [20].

Таким чином, інтерес в історичному аспекті, починаючи з поділу на приватний та публічний, завжди відігравав важливу роль у державному правлінні. У практиці державних відносин інтерес сприяв пошукам спільних підходів, альтернативних можливостей та нових візій розвитку. Правова доктрина, розвиваючи питання щодо інтересу, зуміла виділити елемент конфліктності під час узгодження особистого та державного суверенітету, а також надала вагомого значення індивідуальним трансформаціям особи та ії свідомості, від позитивних чи негативних наслідків якої змінюється і розуміння інтересу. Сучасне конституційне право, як остання та основна ланка цих зв'язків, наповнене нормами, які, з одного боку, дозволяють реалізовувати інтерес у публічній чи приватній сфері, а з іншого, здійснюють його обмеження для ефективного забезпечення суспільної справедливості, тобто балансу між його публічними та приватними проявами.

Останній елемент нашого огляду, який чітко виокремлюється в більшості проаналізованих напрямків та є невід’ємною складовою частиною всіх державних процесів, - це закон та його інструментальне використання.

Із застосуванням ретроспективного методу закон у поглядах науковців виступав способом запобігання зловживанню владою (Н. Мак'явеллі). Проте І. Кант вважав, що правитель із великою душею в силі стримувати власні примхи та керувати на засадах права і суворого дотримання закону $[5$, с. 158,198$]$. Арістотель стверджував, що закон не може бути змінений людиною, яка керується власним інтересами, що суперечать державним. При цьому ставив вимогу перед сутністю закону - який повинен бути результатом врівноваженого розуму [30, с. 63]. У сьогоднішньому розумінні це спосіб реалізації справедливості, тобто балансу між публічними та приватними інтересами. Про антропоцентричне використання закону також згадувалося і в Біблії, у главі 31 , віршах 4-5 Книги приповістей Соломонових написано: «Не царям, Ленуїле, вино, не царям, i напій той п’янкий не князям, щоб не впився він та не забув про Закон, і щоб не змінив для всіх гноблених права!» $[7$, с. 741].

Практика державотворення має приклади використання права «вето» як способу впливу на прийняття закону. Президент Республіки Польща А. Дуда наклав вето на два із трьох законів, якими посилювався вплив парламенту та генерального прокурора на судову гілку влади. При цьому главі держави знадобилося близько 10 днів для накладення вето, хоча він мав цілих три тижні $[46 ; 10]$. У цьому випадку варто звернути увагу на оперативність застосування правового інструментарію, що було «швидко і без зволікань». Президент Чеської Республіки В. Гавел, коментуючи використання свого права «вето», стверджував, що не сприймає це право як турнір із тенісу, а його поведінка узгоджується із совістю та відчуттям справедливості. Якщо його погляди будуть переголосовані, то він схилить голову перед колективним розумом парламенту. У такий спосіб В. Гавел демонстрував повагу як перед парламентом, так і перед народом [40, с. 91]. Окрім права «вето», основним законом передбачено також гарантії захисту, які, наприклад, для професійного судочинства відіграють ключову роль. У посібнику для суддів «Бути суддею» суддя зі свого досвіду згадує ситуацію, коли до всіх членів колегії суддів були застосовані погрози від однісї зі сторін справи. У тій ситуації всі судді зійшлися на тому, що прийняття законного рішення гарантуватиме подальший захист і право на відстоювання своєї позиції. У ситуації іншого судді 
здійснювався тиск із боку керівництва суду: «Коли виникли спроби тиску з боку голови суду, важливо було зробити так, як велів закон і цього виявилося достатньо» $[14$, с. $73-74,76]$.

Науково-правове розуміння взаємодії закону та антропоцентризму було цікаво висвітлено в посиланні М. Салей на О. Костенка, який у публікації «Конституція і ідеологія: проблема співвідношення» писав, що законодавство - це інструмент у руках людей, які його застосовують, а саме застосування залежить від стану їхньої волі та свідомості [Цит. за 43, с.179], [22, с. 87-93]. Проте варто зазначити, що Арістотелеве розуміння закону як врівноваженого розуму знаходить відображення і в сучасній доктрині. 3 одного боку, науковці обгрунтовують явище, коли службова особа має необхідність та можливість використовувати дискреційні повноваження, тобто приймати рішення на власний розсуд $[9$, с. 8]. 3 іншого боку, попри те, що людина може впливати на державотворчі події, виходячи із власного розсуду, iї вплив має правові межі, передбачені, перш за все, вже згаданими політичними правами громадян та механізмом реалізації права на участь у державних справах, а також відповідальністю, яка визначає сутність та значення повноважень $[50$, с. $11 ; 62$, с. 8].

Визначення місця закону у взаємодії із людським чинником суб'єкта владних повноважень на рівні конституційного законодавства в першу чергу відображається згаданим у практиці державотворення правом «вето» (п. 30 ст. 106, ч. 2 ст. 94 КУ; п. 5 ст. 122, пП. 6 п. 3 ст. 144 КП; п. 1 ст. 50 , п. h) ст. 62 КЧ;), яке робить можливим сильний вплив президента на законотворчий процес $[2 ; 3 ; 51 ; 20]$. Невід'ємне місце займає сфера, врегульована розсудом державного службовця дискреційними повноваженнями, наприклад, згідно $з$ п. 10 ст. 106 КУ Президент робить подання на призначення Міністра оборони України та Міністра закордонних справ України. Хоча призначення ухвалюється парламентом, вибір осіб на призначення здійснюється на власний розсуд самого Президента [20]. Елементом правового статусу, в якому особа зобов'язується обмежити себе законом, $є$ обов'язок у формі присяги. Наприклад, згідно зі ст. 130 КП Президент присягає зберегти вірність приписам конституції. Обов'язок у формі прямої вказівки п. 1 ст. 178 цієї ж конституції передбачено, що суддя у своїй діяльності є незалежним і підконтрольним лише закону $[3 ; 51]$. Закон впливає на інтереси суб'єкта публічної влади через заборони та обмеження, які описані вище. Окрім можливостей, необхідностей та обмежень нормативним актом також передбачаються гарантії щодо настання відповідальності (п. 1 ст. 105 КП - за порушення депутатом прав третіх осіб відповідальність настає за згоди Сейму), захисту (ст. 26 КЧ - виконання повноважень парламентарів здійснюється особисто та не зв'язане жодними інструкціями) і забезпечення (ч. 4 ст. 12 КФ - після розпуску Національних Зборів розпуск нового складу парламенту не може бути раніше, ніж через рік після виборів (забезпечення роботи протягом року)) $[3 ; 51 ; 2 ; 1 ; 52]$.

Закон пройшов тривалий шлях - від ідеї до сучасного нормативного втілення. Сутність урівноваженого розуму, якою він наповнювався у своїх витоках, сьогодні здобула: практичний прояв через емпіричність його ветування та гарантування ним захисту; доктринальне поглиблення у співвідношенні волі, свідомості та його інструментального використання; нормативного втілення на рівні конституційного (та інших форм) законодавства через збалансованість правових можливостей, необхідностей, інтердикційності (поєднання обмежень і заборон) та гарантій відповідальності, захисту і забезпечення суб'єкта владних повноважень. Це створює ефективну інтеракцію між законом та суб'єктом його впливу чи застосування, що дає підгрунтя для обрамлення явища антропоцентризму як у конституціоналізмі, так і в законодавстві в цілому, та веде до подальшого розвитку.

Висновки. Таким чином, у проведеному дослідженні систематизовано динаміку та процеси переходу правових явищ від історичних витоків через практику державотворення та доктринального досвіду до сучасного юридичного втілення. Описані процеси створюють передумови для теоретичного визначення місця та ролі атропоцентризму в конситуційному праві, однак логічне узагальнення потребує окремого наукового дослідження, яке буде зроблено в подальшому.

\section{Список використаних джерел:}

1. Constitution of France Republic 1958. URL : https://www.conseil-constitutionnel.fr/sites/ default/files/as/root/bank_mm/anglais/constiution_anglais_oct2009.pdf.

2. Constitution of The Czech Republic. 1992. URL : https://www.usoud.cz/fileadmin/user upload/Tiskova_mluvci/Ustava_EN_ve_zneni_zak_c._98-2013.pdf.

3. Constitution of the Republic of Poland. 1997. URL : http://www.sejm.gov.pl/prawo/konst/ angielski/kon1.htm.

4. Барабаш Ю.Г. Державно-правові конфлікти на сучасному етапі державотворення : автореф. дис. на здобуття наук. ступеня докт. юр. наук : спец. 12.00.02 «Конституційне право;муніципальне право». Харків, 2009. 35 с. 
5. Безродний С.Ф. Світова класична думка про державу і право. Київ : Юрінком Інтер, 1999. 400 с.

6. Бернар Б. Чому Н. Саркозі був видатним президентом. URL : https:/ipress.ua/mainmedia/ chomu_nikolya_sarkozi_buv_vydatnym prezydentom_1576.html.

7. Біб̈лія або книга Святого Письма Старого й Нового Заповіту. Пер. І. Огієнка, 2006. 1375 c. C. 741.

8. Боднар Н. Досягнення і провали Порошенка: що зробив президент для України за 5 років. 2019. URL : https://24tv.ua/petro_poroshenko_yak_prezident_ukrayini_dosyagnennya_provali_za_5_ rokiv_n114474.

9. Ботнаренко О.М. Дискреція в юридичній діяльності: юридико-психологічні особливості : автореф. дис. на здобуття наук. ступеня канд. юр. наук : спец. 19.00 .06 «Юридична психологія». Київ, 2010. 20 с.

10. Віленський Я. Президент Польщі: «двічі вето». Голос України. 2017. URL : http://www.golos.com.ua/article/291692.

11. Гавел В. Прошу коротко. Розмова з Карелом Гвіждялою, примітки, документи. Львів : ПАІС, 2016. $288 \mathrm{c}$.

12. Гегель Г. Основи філософії права, або Природне право і державництво / Пер. 3 нім. Р. Осадчука та М. Кушніра. Київ : Юніверс, 2000. 336 с.

13. Гоббс Т. Левіафан. Київ : Дух і літера, 2000. 606 с.

14. Денисенко Л., Сироїд О., Фадєєва І., Шаповалова О. Бути суддею. Київ : ТОВ «Друкарня «Бізнес поліграф», 2015. 216 с.

15. Енциклопедія сучасної України / I.М. Дзюба, А.І. Жуковський, О.М. Романів, О.М. Железняк. Київ : Інститут енциклопедичних досліджень, 2001. Т. 1. 823 с.

16. Євсєєв О.П. Процедури в конституційному праві України : дис. канд. юр. наук : 12.00.02. Харків, 2008. $220 \mathrm{c}$.

17. Зв'ягіна О. М. Олександр Кваснєвський - архітектор нової зовнішньої політики Польщі. Наукові праці історичного факультету Запорізького національного університету. 2012. № 32. C. $351-356$.

18. Зміна уряду в Польщі: оголошені прізвища звільнених і нових міністрів. Свропейська правда. 2018. URL : https://www.eurointegration.com.ua/news/2018/01/9/7075816/.

19. Зубрицька О.Я. Особа як індивібуальний суб'єкт адміністративного права : дис. канд. юр. наук : 12.00.07. Київ, 2015. 214 с.

20. Конституція України. Відомості Верховної Ради України (ВВР). 1996 № 30. Ст. 141. 1996. URL : https://zakon.rada.gov.ua/laws/show/254к/96-вр.

21. Концепція політичного лідера у працях Н. Макіавеллі. HUMANITIES \& SOCIAL SCIENCES 2011. URL : http://ena.lp.edu.ua:8080/bitstream/ntb/19322/1/62-Markitantov-186-189.pdf.

22. Костенко О. Конституція і ідеолоія: проблема співвідношення. Конституційні засади державотворення і правотворення в Україні. 2006. С. 87-93.

23. Коцкулич В.В. Формування професійної правосвідомості судді та суддівського розсуду: організаційний та праксеологічний аспекти : дис. канд. юр. наук : 12.00.10. Київ, 2018. 233 с.

24. Ладиченко В.В. Гуманістичні основи організації державної влади : автореф. дис. на здобуття наук. ступеня докт. юр. наук : спец. 12.00.01 «Теорія та історія держави і права;історія політичних і правових вчень». Київ, 2008. 41 с.

25. Макушев П.В. Професійна правосвідомість і правова культура дільничого інспектора міліції : автореф. дис. на здобуття наук. ступеня канд. юр. наук : спец. 12.00.01 «Теорія та історія держави і права; історія політичних і правових вчень». Київ, 2004. 22 с.

27. Мак'явеллі Н. Флорентійські хроніки. Державець. Харків : Фоліо, 2007. 511 с.

28. Малишев Б. Вчення Рудольфа фон Єринга про мету в праві. Вісник Київського начіонального університету ім. Тараса Шевченка. 2010. № 82. С. 33-36.

29. Матіос А.В. Адміністративна відповідальність посадових осіб у сфері державного управління : автореф. дис. на здобуття наук. ступеня канд. юр. наук : спец. 12.00.07 «Теорія управління;адміністративне право і процес;фінансове право;інформаційне право». Київ, 2006. 21 с.

30. Меленко С.Г. Арістотель про соціальні основи держави. Держва і права. № 56. С. 60-65.

31. Мор Т. Утопія. Місто Сонця. Пер. $з$ лат. Вступ слово Й. Кобова та Ю. Цимбалюка ; передм.Й. Кобова. Київ : Дніпро, 1988. 207 с.

32. Нефьодов Максим Євгенович. URL : https://is.gd/rtIIJn.

33.Максим Нефьодов. Рандеву. 2017. URL : https://www.youtube.com/watch?v=a2h9WejjMPI.

34. Нинюк I.I. Професіоналізм державних службовців: сутність, стан та особливості формування : автореф. дис. на здобуття наук. ступеня канд. юр. наук : спец. 25.00.03 «Державнв служба». Київ, 2005. 17 с. 
35. Ніколя Саркозі. Конституційна реформа. URL : https://bit.ly/31mvoxD.

36. Олланд Ф. Уроки влади: мемуари. Харків : «Фоліо», 2019. 444 с.

$232 \mathrm{c}$.

37. Олексик Х.М. Історія вчень про державу і право: конспект лекцій. Ужгород : ЗакДу, 2010.

38. Парута О.В. Правова ідентичність особи : дис. канд. юр. наук : 12.00.01. Львів, 2016. 246 с.

39. Підопригора О.А. Римське право : підручник. Київ : Юрінком Інтер, 2009. 528 с.

40. Паславський I. Політика і журналістика.Вацлав Гавел про журналістику і журналістів. Вісник Львівського університету. Серія Журналістика. 2016. № 41. С. 88-97.

41. Пашко Л.А. Людські ресурси у сфері управління: теоретико-методологічні засади оцінювання : автореф. дис. на здобуття наук. ступеня канд. юр. наук : спец. 25.00 .03 «Державне управління». Київ, 2007. 27 с.

42. Рибалка Н.О. Адміністративно-правові аспекти діяльності Президента України : автореф. дис. на здобуття наук. ступеня канд. юр. наук : спец. 12.00.07 «Адміністративне право і процес; фінансове право;інформаційне право». Київ, 2009. 22 с.

43. Салей М.І. Конституційна аксіологія в сучсній Україні : дис. канд. юр. наук : 12.00.02. Одеса, 2017. 243 с.

44. Серебро М.В. Сучасна держава як цінність: загальнотеоретичне дослідження : автореф. дис. на здобуття наук. ступеня канд. юр. наук : спец. 12.00.01 «Теорія та історія держави і права;історія політичних і правових вчень». Одеса, 2017. 24 с.

45. Смілик А.С. Свобода і відповідальність як філософсько-правові засади формування законослухняності особи : дис. канд. юр. наук : 12.00.01. Львів, 2016. 195 с.

46. Судова Реформа в Польщі. URL : https://bit.ly/2YTfpVU.

47. Терент’єва О.Л. Менталітет як чинник розвитку державотворення в України : автореф. дис. на здобуття наук. ступеня канд. юр. наук : спец. 25.00.01 «Теорія та історія державного управління». Харків, 2010. 18 с.

48. У Польщі депутати Сейму зменшили собі зарплатуна 20\%. Молодий буковинець. 2017. URL : https://molbuk.ua/world/149571-u-polschi-deputaty-seymu-zmenshyly-sobi-zarplaty-na-20.html.

49. Філософія права : підруч. для студ. юрид. вищ. навч. закл. / О.Г. Данильян, О.П. Дзьобань, С.І. Максимов та ін. / за ред. д-ра філос. наук, проф. О.Г. Данильяна. Харків : Право, 2009. $208 \mathrm{c}$.

50. Чуб О.О. Конституційне право громадян України на участь в управлінні держаними справами : автореф. дис. на здобуття наук. ступеня канд. юр. наук : спец. 12.00 .02 «Конституційне право». Харків, 2004. 23 с.

51. Шаповал В.М. Конституція Польської Республіки (з передмовою Володимира Шаповала). Київ : Москаленко О.М., 2018. 82 с.

52. Шаповал В.М. Конституція Французької Республіки (з передмовою Володимира Шаповала). Київ : Москаленко О.М., 2018. 56 с.

53. Шевченко Т.О. Законодавче регулювання припинення повноважень народного депутата України : автореф. дис. на здобуття наук. ступеня канд. юр. наук : спец. 12.00 .02 «Конституційне право;муніципальне право». Київ, 2010. 20 с.

54. Юрченко С.В. Зовнішньополітичні виклики державі в баченні Президентів України, 1991-2012 рр. / Інститут Президента України в системі держаної влади України: матеріали наукової конференції. 2014. С. 129-134.

57. Якимович Я.В. Антропоцентризм у державній владі: аналіз норм основних законів у країнах Центральної та Східної Європи (Франція Чехія Польща та Україна). Юридичний науковий електронний журнал. 2019. URL : http://www.lsej.org.ua/3_2019/12.pdf.

58. Якимович Я.В. Антропоцентризм у державній владі: конституційний огляд емпіричних фактів державного правління у країнах Центральної та Східної Європи (Франція, Чехія та Польща). Актуальні проблеми вітчизняної юриспруденції. 2019. № 5.

59.Якимович Я.В. Антропоцентризм у державній владі: конституційний огляд емпіричних фактів державного правління в Україні. Право та державне управління. 2019. № 3.

60. Якимович Я.В. Антропоцентризм у державному механізмі: генезис поглядів. Науковий вісник Ужгородського національного університету. Серія право. 2018. № 48 (Том 1). С. 52-55.

61 Якимович Я.В. Антропоцентризм у державному механізмі : аналіз сучасних доктринальних підходів у праві. Конституиійно-правові академічні студіï. 2018. № 2. С. 87-96.

62. Янюк Н.В. Адміністративно-правовий статус посадової особи : автореф. дис. на здобуття наук. ступеня канд. юр. наук : спец. 12.00 .07 «Теорія управління;адміністративне право і процес;фінансове право». Київ, 2003. 25 с. 